\title{
A Solution to the Many Attitudes Problem
}

\author{
Bob Beddor \\ Philosophical Studies, forthcoming
}

\begin{abstract}
According to noncognitivism, normative beliefs are just desire-like attitudes. While noncognitivists have devoted great effort to explaining the nature of normative belief, they have said little about all of the other attitudes we take towards normative matters. Many of us desire to do the right thing. We sometimes wonder whether our conduct is morally permissible; we hope that it is, and occasionally fear that it is not. This gives rise to what Schroeder calls the 'Many Attitudes Problem': the problem of developing a plausible noncognitivist account of the full range of attitudes that we take towards normative matters. This paper explores the problem and proposes a solution.
\end{abstract}

\section{The Problem}

We all have normative beliefs. I believe that lying is wrong, and presumably you do too. But what does this belief involve?

One answer comes from the cognitivist, who maintains that normative belief is much like descriptive (that is, non-normative) belief. According to the cognitivist, both normative and descriptive beliefs represent the world as being a certain way. Someone who believes that sea levels are rising is in a psychological state that represents the world as one where sea levels are rising. Similarly, someone who believes that lying is wrong is in a psychological state that represents the world as one where lying is wrong.

The noncognitivist tells a different story. While descriptive beliefs aim to represent the world, normative beliefs do not. According to the noncognitivist, normative beliefs are really just conative attitudes-states of desire, approval, and the like. On a simple version of this picture, all it is to believe that lying is wrong is to disapprove of lying. ${ }^{1}$

\footnotetext{
${ }^{1}$ In the early years, noncognitivists proclaimed that there are no normative beliefs (e.g., Ayer 1936). But
} 
While the noncognitivist picture is highly controversial, even its critics usually admit that it has some appealing features. Two in particular are worth highlighting. First, since desire-like states are inherently motivational, noncognitivism explains why someone who believes that lying is wrong will-at least in normal circumstances-be pro tanto motivated to avoid lying. ${ }^{2}$ Second, since noncognitivism takes normative belief to be a conative relation towards descriptive propositions, it offers to explain normative thought in fully naturalistic terms.

Despite its appeal, noncognitivism faces significant challenges. By now, much ink has been spilled over the most well-known of these challenges-in particular, the FregeGeach Problem. In this paper, I investigate a problem that has received comparatively little attention.

The problem starts with the observation that belief is not the only attitude we take towards normative matters. Consider Lyle the compulsive liar. Lyle might desire to do the right thing. As a result of this desire, he might wonder whether lying is morally permissible. He might hope that it is, and fear that it is not. What do these attitudes involve?

For cognitivists, there is no great mystery here. Just as normative belief and descriptive belief are the same sort of psychological state, so too are normative hope and descriptive hope (and likewise for the other attitudes). Thus cognitivists can say, 'Give me your favorite story about what's involved in hoping for a promotion, or world peace, or what have you. On my view, to hope that lying is permissible is to be in the same sort of psychological state, just with a normative proposition as its content.'

But what should noncognitivists say? This is far from clear. If normative belief is just a conative attitude, what is normative hope (or fear, or desire)? Are these conative attitudes as well? If so, can we say anything systematic about how these attitudes relate to-and differ from-the conative attitude that constitutes normative belief?

Following Schroeder, call this the 'Many Attitudes Problem.' Thus far, noncognitivists have said little about this problem. Many noncognitivists have developed detailed accounts of the conative attitude that constitutes normative belief, and a few have also

contemporary noncognitivists have sought to distance themselves from the more radical proclamations of their intellectual forebears. Contemporary 'quasi-realists' allow that there are normative beliefs. It's just that normative beliefs are best understood as desire-like states (Blackburn 1993, 1998; Gibbard 2003; Yalcin 2012). For further discussion of the quasi-realist notion of belief, see Ridge (2006a); Köhler (2017).

${ }^{2}$ For versions of this ‘Argument from Motivation' for noncognitivism, see Blackburn (1998: 61); Stevenson (1937: 16); Gibbard (2003: chp.7). For critical discussion, see Svavarsdóttir (1999).

${ }^{3}$ See Schroeder (2008b: 715-716; 2010: 84; 2013b: 414-415). See also Shiller (2017). 
discussed related attitudes, such as credence and knowledge. ${ }^{4}$ However, none has ventured beyond these 'belief-y' attitudes; none has offered a systematic account of nondoxastic attitudes towards normative matters. ${ }^{5}$

This lacuna is both surprising and worrisome. It is surprising, because noncognitivists aspire to give an account of all normative thought. Given this lofty ambition, the standard practice of focusing on one species of normative thought-the doxastic attitudes-seems parochial. And it is worrisome, because if noncognitivists cannot give a plausible account of the nondoxastic attitudes, then their entire project is doomed.

\section{The Game Plan}

This paper develops a solution to the Many Attitudes Problem on behalf of noncognitivists. As a general strategy, I suggest that we start by investigating the functional roles of various nondoxastic attitudes. It's uncontroversial that the functional roles of different propositional attitudes are interconnected. It's more controversial-but, I'll argue, still plausible-that the functional roles of a wide variety of attitudes can be at least partially characterized in terms of two privileged attitudes, belief and desire.

To motivate this idea, consider: what is it to hope that $p$ ? As a very rough first pass, hoping that $p$ seems to involve having some positive degree of belief in $p$, as well as a desire for $p$. What is it to fear that $p$ ? As a very rough first pass, fearing that $p$ also seems to involve having some positive degree of belief in $p$, as well as a desire-specifically a desire for $\neg p$. Generalizing from examples like this, we might venture the following big picture hypothesis:

Belief-Desire Reduction: A wide variety of propositional attitudes have a functional

\footnotetext{
${ }^{4}$ For noncognitivist accounts of belief, see Gibbard (1990, 2003); Köhler (2013); Björnsson and McPherson (2014). For noncognitivist theories of credence, see Sepielli (2012); Eriksson and Olinder (2016); Ridge (2018). For noncognitivist takes on knowledge, see Blackburn (1996); Gibbard (2003: chp.11).

${ }^{5}$ The one exception is Köhler (2017: 205-207), who briefly discusses how noncognitivists might understand normative desire, as well as the attitude of entertaining the thought that... While there are some important differences between our approaches (see fn. 14), I am broadly sympathetic to Köhler's suggestions. Indeed, the project of this paper is to systematically expand something in the spirit of Köhler's compressed remarks into a full-fledged theory of normative attitudes.
} 
core that can be specified in terms of some combination of belief and desire. ${ }^{6,7}$

Suppose noncognitivists were to embrace this hypothesis. Then the Many Attitudes Problem becomes considerably easier. After all, noncognitivists will be able to understand a wide variety of attitudes towards normative matters in terms of two more basic attitudes: normative belief and normative desire. Now, we've already noted that noncognitivists have developed detailed accounts of normative belief. Assuming one of these accounts proves viable, all that remains is for noncognitivists to explain normative desire.

Can this be done? I'll argue that there are grounds for optimism. According to a standard approach in philosophy of mind, the functional role of desire can be characterized in terms of various dispositions. For example, we are often told that desiring $p$ disposes you to take whatever actions you believe will bring about $p$, or to experience pleasure on coming to believe $p$, etc. Now, these dispositions are themselves formulated in terms of what the relevant agent will do-or experience-provided they have certain beliefs. In the case of normative desire, these will be normative beliefs. Assuming noncognitivists can make sense of normative belief, they can use this dispositional approach to make sense of normative desire. Combine this approach with Belief-Desire Reduction and you get a recipe for understanding a wide variety of attitudes in terms of belief.

That's the general strategy. Here's how I'll execute it. §3 discusses some initial moves in response to the Many Attitudes Problem and lays out two desiderata on a solution. $\S 4$ looks at how noncognitivists can make sense of normative desire. The rest of the paper is devoted to using this account of normative desire-together with the noncognitivist's preferred account of normative belief-to get a purchase on various other attitudes, à la Belief-Desire Reduction. §5 considers normative intention; $§ 6$ considers normative hope and fear; $§ 7$ investigates factive attitudes; and $\S 8$ briefly discusses wondering and supposing. $\S 9$ concludes by comparing my approach with an alternative solution that relies on a hybrid expressivist framework.

\footnotetext{
${ }^{6}$ The notion that many propositional attitudes can be reduced to simpler components can be found as far back as Descartes' Passions of the Soul. For contemporary endorsements of Belief-Desire Reduction, see Lewis (1974: 332) and Searle (1983: 31-36). Even when it is not explicitly endorsed, I think that some version of Belief-Desire Reduction can be discerned in the background of many programs in philosophy of mind-for example, the belief-desire theory of intention (§5). For a recent attempt to explain a wide variety of mental phenomena in terms of belief and desire, see Sinhababu (2017).

${ }^{7}$ There are different ways of fleshing out Belief-Desire Reduction, depending on how one thinks the reduction goes. In order for my strategy to get off the ground, I only need the claim that a wide variety of attitudes can be partially characterized in terms of some combination of belief and desire. I discuss this issue at greater length later in the paper $(§ 4.5)$.
} 


\section{Desiderata on a Solution}

Some might think that the Many Attitudes Problem admits of an easy solution. While old school noncognitivists had no truck with normative propositions, in more recent years noncognitivists have changed their tune. A number of noncognitivists in the quasirealist tradition have taken pains to make sense of some notion of 'propositions' or 'semantic contents' that can be applied to normative discourse. For example, Gibbard (2003, 2013) takes semantic contents to be sets of world, hyperplan pairs, where a hyperplan represents the content of a maximally decided planning state. And Schroeder (2008a, 2013b) develops a noncognitivist view on which semantic contents are pairs of properties, one of which entails the other. ${ }^{8}$ Once the noncognitivist has some suitable notion of semantic content on the table, can't they simply say that any attitude verb-'believes', 'desires', 'hopes', etc.-relates an agent to one of these contents? If so, won't they have solved the Many Attitudes Problem?

However, this easy solution overlooks a crucial part of the noncognitivist program. Recall that one goal of noncognitivism is to explain normative thought using naturalistically respectable resources. For this reason, noncognitivists who invoke normative contents do not simply claim that agents believe these contents. Rather, they give us a detailed psychological story about what it is to believe such contents-a story that is faithful to the key noncognitivist commitments.

For example, Gibbard does not merely claim that people believe sets of world, hyperplan pairs. He also tells us what this involves. Very roughly, to believe a set of world, hyperplan pairs is to plan to act and feel in various ways. Since plans are conative states, this story offers to vindicate the noncognitivist link between normative belief and conation. And since the contents of these plans are specified without recourse to normative notions, this story also makes good on noncognitivism's naturalistic ambitions. ${ }^{9}$

We are now in a position to see what is wrong with the easy solution to the Many Attitudes Problem. The problem is that while noncognitivists have offered detailed, naturalistically respectable accounts of what is involved in believing normative contents, they have not yet offered analogous accounts of what is involved in hoping for (or fearing, or desiring ...) normative contents. This is precisely where the Many Attitudes

\footnotetext{
${ }^{8}$ One standard motivation for appealing to noncognitivist contents is to solve the Frege-Geach Problem. See, in particular, Gibbard (1990: chp.5; 2003: chp.3).

${ }^{9}$ Similarly, Schroeder does not simply say that people believe pairs of properties. He tells us what this involves: to believe a pair of properties $\left\langle\pi_{1}, \pi_{2}\right\rangle$ is to be for both $\pi_{1}$ and $\pi_{2}$, where being for is a desire-like state.
} 
Problem gets its bite: the hard work is to explain what is involved in hoping for some set of world, hyperplan pairs (for example), and to do so in naturalistically respectable terms.

This suggests the following desideratum on a solution to our problem:

Explanatory Requirement: For any attitude $\alpha$ that it is possible to adopt towards some normative matter $\eta$, a solution to the Many Attitudes Problem should explain the central psychological features of adopting $\alpha$ towards $\eta$. And it should do so in a way that is consistent with noncognitivism's naturalistic ambitions.

A second desideratum is due to Schroeder $(2010,2013 \mathrm{~b})$. Schroeder observes that normative desire has a lot in common with descriptive desire. For example, both play a similar role in explaining action. If someone desires a pizza, we expect them to perform actions aimed at pizza-acquisition. If someone desires to do good, we expect them to perform actions aimed at bringing about the good. A solution to the Many Attitudes Problem should explain these commonalities. That is:

Commonality Requirement: A solution to the Many Attitudes Problem should explain why attitudes towards normative matters share many properties with the corresponding attitudes towards descriptive matters.

Now comes the hard part: developing a theory of normative attitudes that satisfies these desiderata. To do so, I'll start with normative desire (§4). Once we've seen how noncognitivists can make sense of normative desire, I'll appeal to our big picture hypothesis about propositional attitudes (Belief-Desire Reduction) to show how we can get a grip on a host of other attitudes (§§5-8).

\section{Desire}

What is the functional role of desire? Most philosophers who have tackled this question agree on this much: someone who desires $p$ has a different suite of dispositions than someone who believes (or imagines, or regrets) that $p$. However, that's where the consensus ends; there is considerable disagreement over which dispositions are necessary and sufficient for desire.

For our purposes, we need not wed ourselves to any particular answer to this question. Rather, I'll review the two main dispositional conditions on desire in the current literature. I'll show that both conditions can be extended to normative desire in a way that 
is fully consistent with noncognitivism. This should make us optimistic that noncognitivists can explain the functional role of normative desire using standard dispositionalist resources.

\subsection{Dispositions to Act}

Ask your average philosopher to give an account of desire, and chances are they will say something about its role in motivating action. ${ }^{10}$ As a first pass: if Alison desires to eat pizza, then we'd expect this desire to motivate her to eat pizza. But this simple formulation isn't quite right. After all, desires do not motivate action all by themselves, but only in conjunction with beliefs about how to achieve the objects of desire. Alison's desire for pizza will be of little help unless it is accompanied by a belief about the means of pizza-acquisition.

Here's a more promising way of fleshing out a motivational condition on desire:

Dispositions-to-Act If $\mathrm{S}$ desires $p$, then $\mathrm{S}$ is disposed to perform whatever action(s) $\mathrm{S}$ believes has the best chance of satisfying $p$.

While more plausible than our first pass formulation, Dispositions-to-Act still faces various challenges. To mention just one concern, some might worry that it delivers the wrong results in cases where the most effective means of bringing about your desire conflicts with something else you desire. For example, Gunther desires to alleviate his hunger. He knows that eating a peanut butter sandwich would do the trick. Still, if he has a deadly peanut allergy he might have no disposition whatsoever to eat the sandwich. ${ }^{11}$

For our purposes, we need not be overly concerned with counterexamples along these lines. After all, our goal is not to defend any particular dispositional condition on desire, but rather to show how various candidate conditions can be understood from a noncognitivist perspective. That said, it will be helpful to briefly remark on how proponents of a motivational condition on desire might try to defuse this sort of worry. One promising option is to point out dispositions can be masked (Johnston 1992). Suppose a fragile vase is dropped. Typically it will manifest its fragility by breaking. But not if some external factor intervenes, say, a pillow, bubble wrap, a guardian angel. Applied to Gunther: perhaps the belief that eating the peanut butter sandwich will alleviate his hunger

\footnotetext{
${ }^{10}$ This idea that desire is connected with motivation traces back at least as far as Hume's Treatise. For contemporary developments of this idea, see Anscombe (1957); Stalnaker (1984); Smith (1987), among many others.

${ }^{11}$ Thanks to a referee for raising this sort of case.
} 
does generate a very weak disposition to eat the sandwich. But this disposition is masked by his much stronger desire to stay alive. After all, since Gunther knows that consuming the sandwich is likely to have fatal consequences, Dispositions-to-Act predicts this desire will generate a countervailing-and presumably much stronger-disposition to abstain.

Suppose then that we accept Dispositions-to-Act, or at least something in the ballpark. Let us now tackle our main question: can the noncognitivist use this condition to make sense of normative desires?

I claim the answer is yes. To see why, it will be helpful to consider a concrete case of a normative desire. Awaking Monday morning, Michelle desires the following:

NO WRONG: I do nothing wrong today.

According to Dispositions-to-Act, Michelle's desire for NO WRONG consists-in partin a disposition to act in whatever ways she believes will ensure that she avoids wrongdoing. For example, suppose Michelle has promised to see a movie with a friend and believes it would be wrong for her to break this promise. Thus she believes:

PROMISE: The only way to ensure that I do nothing wrong today is to keep my promise.

Dispositions-to-Act predicts that Michelle will be disposed to keep her promise.

Noncognitivists can happily accept all of this. Where they part ways with the cognitivist is in their account of the relevant means-ends belief (PROMISE). For the noncognitivist, Michelle's belief in PROMISE is itself a nonrepresentational, desire-like state. For example, noncognitivists like Gibbard will analyze Michelle's belief in PROMISE as a 'contingency plan': a pro tanto plan to blame herself for failing to keep her promise, in the contingency that she fails to do so.

Of course, if Michelle's belief in PROMISE is itself a desire-like state, then this will involve further dispositions to act. But no vicious regress looms. According to Dispositionsto-Act, Michelle's belief in PROMISE will dispose her to act in whatever ways she believes will ensure that she keeps her promise. Crucially, these further beliefs are descriptive, not normative. (For example, they will be beliefs of the form: Going to the movie at such-and-such a time is a way of ensuring I keep my promise.) 


\subsection{Dispositions to Experience}

Another prominent line of thought holds that desires involve dispositions to undergo certain experiences. ${ }^{12}$ This idea holds considerable pretheoretic appeal. If Bree wants the Mets to win, we'd expect her to experience positively valenced emotions-joy, satisfaction, contentment-if she learns that the Mets won. We'd also expect her to experience negatively valenced emotions-disappointment, discontent, sorrow-if she learns that the Mets lost.

Here is one way of cashing out this idea more generally:

Dispositions-to-Experience: If $\mathrm{S}$ desires that $p$, then $\mathrm{S}$ is disposed to experience pleasure in the event that $\mathrm{S}$ comes to believe $p$, and $\mathrm{S}$ is disposed to experience displeasure in the event that $\mathrm{S}$ comes to believe $\neg p{ }^{13}$

Can noncognitivists use an experiential condition along these lines to make sense of normative desires? I think so. According to Dispositions-to-Experience, if an agent has a normative desire, they are disposed to undergo certain experiences on coming to hold various normative beliefs. Since noncognitivists already have an account of normative beliefs, they should have no trouble making sense of a disposition to experience pleasure or displeasure on coming to hold normative beliefs.

To illustrate, return to Michelle, who desires NO Wrong. According to Dispositionsto-Experience, this entails that she is disposed to experience pleasure on coming to believe that she has done no wrong, and disposed to experience displeasure on coming to believe that she has acted wrongly. Now, the noncognitivist already has an account of what it is for Michelle to come to believe No wrong (or its negation). Here too, this will be a matter of acquiring some conative state. For example, on Gibbard's (2003) view this will be a matter of Michelle acquiring a plan to refrain from blaming herself for any actions performed on Monday.

\subsection{Taking Stock}

In this section, I've sketched a recipe for developing a noncognitivist theory of normative desire. The recipe was to look at two leading candidates for a dispositional condition on normative desire and show that both can be squared with noncognitivism.

\footnotetext{
${ }^{12}$ For development and defense of this idea, see Morillo (1990); Strawson (1994); Schueler (1995); Sinhababu (2017), among others.

${ }^{13}$ Note that since both Dispositions-to-Act and Dispositions-to-Experience are formulated as necessary conditions on desire, the two are perfectly compatible.
} 
Of course, some might think that the functional role of desire is not exhausted by these two dispositions. However, my recipe extends in principle to any number of further features of desire. For any dispositional feature $f$, the key question is whether we can formulate its stimulus condition using resources that are already in the noncognitivist toolkit. If so, the noncognitivist can use the strategy developed here to get a grip on $f$.

The account of normative desire that emerges has a number of virtues. First, it satisfies the Explanatory Requirement. It does not merely say that agents stand in the desire relation to some expressivist content. Rather, it gives a substantive account of what normative desire involves, and it does so in a way that is consistent with the noncognitivist's naturalistic project.

Second, it satisfies the Commonality Requirement. On the framework developed here, what unites normative and descriptive desires is that they share a common dispositional role.

Third, my treatment of normative desire is independently motivated, in the sense that it does not make any ad hoc stipulations about what normative desire involves. Rather, we started with commonly accepted conditions on the functional role of desire. We then combined these with the noncognitivist conception of normative belief, and we got our noncognitivist conditions on normative desire as an immediate result. ${ }^{14}$

Before moving on to other nondoxastic attitudes, let me address some natural concerns that might arise for this account.

\subsection{Objections Addressed}

Objection: 'Perhaps some normative desires motivate action-for example, Michelle's desire to avoid wrongdoing. But many normative desires seem to lack any motivational

\footnotetext{
${ }^{14}$ My recipe for developing a noncognitivist account of normative desire bears comparison with the account in Köhler (2017: 205-207), which was developed independently and is, to my knowledge, the only published discussion of how expressivists should analyze desire. On Köhler's account, descriptive desire and normative desire have different "conceptual roles." The conceptual role of desiring a descriptive proposition is to motivate action, à la Dispositions-to-Act (p.205). By contrast, Köhler denies that normative desires motivate action. Instead, the conceptual role of desiring some normative proposition $p$ is dispose one to "take pleasure in entertaining the thought that $p$ ", to have one's attention drawn to the thought that $p$, and to entertain this thought in a "fantasizing manner" (p.206).

Köhler's description of the conceptual role of normative desire has some important similarities to Dispositions-to-Experience. In this regard, our approaches are complementary. That said, there is also a major difference: since Köhler denies that normative desires motivate action, he is not able to derive the conceptual role of normative desire as a special instance of a more general conceptual role shared by all desires.
} 
pull. Recall Lyle the compulsive liar. Lyle might want lying to be morally permissible. But we wouldn't expect him to perform any actions aimed at rendering lying permissible.'

Reply: In response, it will be helpful to make two points. First, we should note that this objection doesn't reveal anything special about normative desires. After all, we can come up with descriptive desires that also seem to lack motivational pull. Meet Claude, who desires to have been born with royal blood. Even though he has this desire, we wouldn't expect Claude to perform any actions aimed at giving himself a royal lineage.

Second, and more importantly, such characters are actually compatible with a motivational condition on desire. Here is a natural way of unpacking Dispositions-to-Act:

Dispositions-to-Act (Unpacked) If $\mathrm{S}$ desires $p$, then, for any action $\phi, \mathrm{S}$ has the following disposition: to $\phi$ in the event that $\mathrm{S}$ comes to believe that $\phi$-ing has the best chance of satisfying $p .{ }^{15}$

Thus unpacked, Dispositions-to-Act can make sense of both Lyle and Claude. The reason why Lyle is not disposed to perform any actions aimed at rendering lying permissible is that Lyle believes that there are no such actions. (Presumably Lyle thinks that the moral status of lying is outside of his control.) Still, Lyle plausibly has a conditional disposition: he is disposed to perform various actions conditional on coming to believe that so acting will render lying permissible. For example, he is disposed to pray to a certain deity in the event that he comes to believe that so praying will have a chance of affecting the moral status of lying. (Similar remarks apply, mutatis mutandis, to Claude.)

Of course, there are tricky questions about how to understand such conditional dispositions. For our purposes, we need not try to settle these questions. But to take an off-the-shelf analysis, suppose one adopts a modal account of dispositions (Manley and Wasserman 2008; Vetter 2014; Beddor and Pavese 2018). Then it would be natural to analyze an ascription of the form, ${ }^{\ulcorner} x$ is disposed to $\psi$ in the event that $C^{\top}$ as saying that in a sufficiently high proportion of some relevant domain of worlds where $C$ obtains, $x \psi$ s. On this approach, Lyle has the relevant conditional disposition if and only if in a suitably high proportion of some relevant domain of worlds where Lyle believes that praying to a deity will render lying permissible, he prays to this deity. ${ }^{16}$

\footnotetext{
${ }^{15}$ This is arguably equivalent to interpreting the disposition as taking wide-scope over a conditional-e.g., if $\mathrm{S}$ desires $p$, then, for any action $\phi, \mathrm{S}$ is disposed to ( $\phi$ if $\mathrm{S}$ believes that $\phi$ will bring about $p$ ).

${ }^{16} \mathrm{~A}$ referee points out that a variant of this worry is less easily defused. Consider Kyle, who desires the conjunction c: lying is permissible and I (Kyle) never existed. According to Dispositions-to-Act (Unpacked),
} 
Objection: 'Dispositions-to-Act and Dispositions-to-Experience presuppose that the objects of desires are propositions. When it comes to normative desires, these will be normative propositions-for example, whatever proposition corresponds to NO WRONG. But you haven't told us how to understand these propositions from a noncognitivist perspective.'

Reply: Fair enough. But, as we noted in §3, many noncognitivists in the quasi-realist tradition have already developed theories of normative propositions. So there is nothing in principle to prevent a noncognitivist from making sense of desires towards these entities.

In fact, my account of normative desire makes it easier to defend a noncognitivist account of propositions. ${ }^{17}$ One of the main challenges facing a noncognitivist account of propositions is to show that these 'propositions' are really worthy of the name-that is, to show that they can play the various roles traditionally assigned to propositions. One of these roles is to serve as the contents of propositional attitudes. While noncognitivists like Gibbard have taken pains to show that their normative propositions can serve as the contents of belief, thus far not much work has been done to show they can serve as the contents of other attitudes. The account of desire developed here helps fill this gap.

Objection: 'You claim that normative and descriptive desires share a common dispositional core. But this apparent unity masks a fundamental difference. According to Dispositions-to-Act, whether someone desires some descriptive content depends on what they are disposed to do if they have certain descriptive beliefs. Whether someone desires some normative content depends on what they are disposed to do if they have certain normative beliefs. If normative and descriptive beliefs are very different states (as noncognitivists claim), then there are really two very different dispositional roles here. And similarly when it comes to Dispositions-to-Experience. So your account of desire doesn't satisfy the Commonality Requirement after all.'

this amounts to saying that Kyle is disposed to act in various ways in the event that he comes to believe that so acting will satisfy $c$. But can we even make sense of forming such an absurd belief?

In response, let me make two further points. First, while the belief in question is absurd, it might still be psychologically possible. After all, many people have confused beliefs about the ways in which they could change the past, as the paradoxes of time travel reveal. Second, the problem raised by this case is not specific to normative desires or any noncognitivist theory thereof. After all, the troublesome feature of Kyle's desire is its second conjunct (his desire not to have been born), which is a descriptive content. As long as there is some way for proponents of a motivational condition on desire to make sense of Kyle's desire never to have been born, noncognitivists should be able to appeal to this solution to make sense of the conjunctive desire.

${ }^{17}$ Thanks to a referee for helping me appreciate this point. 
Reply: This is a legitimate challenge. However, noncognitivists already need to satisfy the Commonality Requirement when it comes to belief (Schroeder 2010: 96-97). After all, descriptive and normative beliefs have a lot in common. Just as we can agree or disagree in our descriptive beliefs, we can also agree or disagree in our normative beliefs. Just as our descriptive beliefs can be appraised as coherent or incoherent, so too can our normative beliefs. There also seem to be phenomenological similarities: regardless of whether $p$ is normative or descriptive, believing $p$ usually involves a feeling of 'coming down on' the issue of whether $p$ (Horgan and Timmons 2006).

In the literature, we find two proposals for explaining these commonalities. The first-what I'll call the 'Similarity Strategy'-identifies normative belief with a special type of conative state, one that is belief-like in some respects and desire-like in others. For example, Gibbard (2003) identifies normative beliefs with plans. According to Gibbard, plans-like descriptive beliefs-can stand in disagreement relations. Suppose I plan to go out. Suppose that you have a conflicting contingency plan: you plan, conditional on being in my shoes, to stay home. Then, Gibbard says, our plans disagree (2003: 68-69). Plans can also be assessed for coherence or incoherence: I cannot coherently plan to to go out while also planning to stay home. Arguably, plans also have a similar phenomenology of 'coming down on' some issue: if I plan to go out, then I take myself to have settled the question of whether or not I will go out. According to this strategy, normative belief does not have the exact same functional role as descriptive belief. But the two states have sufficiently similar functional roles to explain the indisputable commonalities.

According to the second strategy-what I'll call the 'Identity Strategy'-normative and descriptive beliefs have the very same functional role, but this functional role is defined in a way that is consistent with core noncognitivist commitments. For example, Schroeder (2008a) proposes the surprising view that both normative and descriptive beliefs are conative attitudes-attitudes of being for. To have a descriptive belief that $p$ is to be for proceeding as if $p$, where to proceed as if $p$ is, roughly, to take $p$ as settled in deciding what to do. ${ }^{18}$

For our purposes, we need not adjudicate between these two strategies.As long as we have some viable explanation of the similarities between descriptive and normative

\footnotetext{
${ }^{18}$ In Beddor (2019), I defend a different version of the Identity Strategy. On the view developed there, normative and descriptive beliefs have the same functional role-a role characterized in terms of their actionguiding potential. However, an agent stands in this belief relation towards a normative proposition just in case they stand in a different psychological relation-in particular, a conative relation-towards some descriptive proposition. As a result, we still vindicate the noncognitivist idea that an agent believes lying is wrong if and only if they desire that no one lies. See Beddor (2019: 15-24) for the details.
} 
beliefs, we can leverage it to account for the similarities between descriptive and normative desires. Proponents of the Identity Strategy can maintain that normative and descriptive desires have the very same functional role. (After all, if believing lying is wrong has the same functional profile as believing the Mets won, then plausibly the state of being disposed to experience pleasure in the event one believes that lying is wrong has the same functional profile as the state of being disposed to experience pleasure in the event one believes the Mets won.) Proponents of the Similarity Strategy won't go quite this far, but they can still maintain that normative and descriptive desires have similar functional roles. Either way, our account of normative desire has good claim to satisfy the Commonality Requirement.

Objection: 'You say that Michelle's desire to do no wrong could combine forces with her belief in PROMISE in order to motivate her to act. But doesn't this run contrary to the spirit of noncognitivism? Noncognitivists usually claim that normative beliefs can $d i-$ rectly motivate us to act without any accompanying desire to do the right thing-indeed, this claim is at the heart of the venerable 'Argument from Motivation.' Consequently, most noncognitivists would hold that someone who believes PROMISE could be directly motivated to keep their promise; they do not need a further desire to do no wrong.'

Reply: Distinguish between two claims: (i) normative beliefs can result in action without an accompanying normative desire, (ii) normative beliefs always result in action without an accompanying normative desire. The account developed here is consistent with (i) but not (ii). However, the Argument from Motivation only supports (i). Indeed, noncognitivists should avoid claiming that our actions are never causally influenced by desires to do good, since this seems patently false.

To see why my account is consistent with (i), imagine the following scenario. As before, Michelle believes PRomise. But this time, she is not disposed to derive any pleasure from learning that she avoided wrongdoing, or to derive any displeasure from learning that she failed to do so. Nonetheless, when it comes time to see the movie with her friend, she trudges off to the cinema, and the reason for this is her belief in PROMISE. In this case, her moral belief results in action, but she does not desire to do no wrong, because the requisite dispositions to experience are absent. ${ }^{19}$

\footnotetext{
${ }^{19}$ Indeed, one advantage of my account of normative desire is that it makes room for agents who desire to do evil. Imagine a further variant of our scenario in which Michelle desires to do something wrong. The account developed here predicts that this desire consists-in part-in a disposition to break her promise, given a belief such as PROMISE. Of course, since her belief in PROMISE is itself a desire-like state, this means
} 


\subsection{Looking Forward}

Having shown how noncognitivists can make sense of normative desires, the next step is to leverage this understanding to get a purchase on other propositional attitudes towards normative matters.

In order to do so, I'll make use of our big picture hypothesis about the structure of propositional attitudes: Belief-Desire Reduction. According to Belief-Desire Reduction, a host of propositional attitudes have a functional core that can be spelled out in terms of some combination of beliefs and desires. If this hypothesis is correct, then noncognitivists can use their account of normative desire-together with their preferred account of normative belief-to make sense of attitudes like intending to do the right thing, fearing one has acted wrongly, etc.

Of course, Belief-Desire Reduction is controversial. However, we need not claim that all propositional attitudes can be fully analyzed in terms of belief and desire. It's fine if there are residual features of the functional profiles of certain attitudes, provided these residual features can themselves be explicated in a way that is consistent with noncognitivism.

To make the case for Belief-Desire Reduction, let's take a closer look at some specific attitudes. Start with intention.

\section{Intention}

What is the functional role of intention? This is a matter of dispute, but let's start with what's relatively uncontroversial. It's widely thought that intention has a doxastic requirement. Exactly how this requirement goes depends on who you ask: some say that intending to $\phi$ entails believing one will $\phi$; others that it entails believing one is likely to $\phi$; still others that it merely requires the absence of a belief that one will not $\phi$. To motivate some version of this doxastic requirement, note that it would be very odd-perhaps downright incoherent-for Michelle to claim, 'I fully intend to go to the movies, but I know for certain that I won't. ${ }^{20}$

A number of philosophers have argued that intention also requires desire: Michelle

that evil Michelle will have conflicting noncognitive attitudes, and hence conflicting dispositions. But this by itself is no cause for concern-indeed, this seems to be precisely what noncognitivists should say about such cases.

${ }^{20}$ For defense of a doxastic condition on intention, see, among others, Grice (1971); Audi (1973); Harman (1976); Davis (1984); Wallace (2001); Marušić and Schwenkler (2018). 
cannot intend to go to the movies unless she desires to go to the movies. This is a bit more controversial than the belief requirement. After all, Michelle might coherently say, 'I intend to go to the movies, because I promised I would. But I'd much rather stay home.' However, at the very least intention seems to display some of the dispositional hallmarks of desire-in particular, its motivational aspect. If Michelle intends to go to the movies, then we'd expect her to be at least somewhat disposed to take whatever actions she believes will direct her towards the cinema.

Noncognitivists can use these belief-desire conditions to get a purchase on normative intention. For example, imagine that Michelle intends to do no wrong. What does this intention involve? According to the belief condition, it involves believing that she will do no wrong-or, at the very least, it involves lacking a belief that she will engage in wrongdoing. According to the desire condition, it also involves desiring to do no wrong-or, at the very least, it involves some of the dispositional hallmarks of so desiring. The noncognitivist can make sense of both of these conditions, since by now they are equipped with accounts of both normative desire and normative belief.

Is any combination of belief and desire sufficient for intention? Proponents of the belief-desire theory of intention say yes: all it takes to have an intention is to have a desire which is accompanied by a means-ends belief about how to satisfy this desire. ${ }^{21}$ However, the belief-desire theory faces a number of important objections. Perhaps the most well-developed critique is due to Bratman (1987), who argues that intention involves a number of functional features that cannot be explained by any combination of beliefs and desires. Luckily, for our purposes we need not take a stand on this dispute. As noted in $\S 4.5$, it's enough if any residual features of the functional role of intention-any features not exhausted by the belief-desire conditions-can be cashed out in noncognitivist-friendly terms.

Moreover, I think there are grounds for optimism on this front. Consider just one feature of intention that-according to Bratman-proves difficult to explain in terms of belief and desire. As we noted in our discussion of Gibbard's view (§4.4), intending to bring about $p$ seems to involve 'settling' the question of whether to bring about $p$. To use Bratman's example, if I intend to spend the afternoon in the library, I'll be disposed to avoid reconsidering whether to spend the afternoon in the library (1987: 18-19). By

\footnotetext{
${ }^{21}$ Versions of a belief-desire theory of intention are defended in Davidson (1963), Audi (1973), Davis (1984); Ridge (1998), and Sinhababu (2013, 2017). Applying the simplest version of the belief-desire theory to normative intention, the idea would be that Michelle intends to do no wrong just in case she both desires to do no wrong and she has a belief about the means of doing no wrong (e.g., a belief such as PROMISE).
} 
contrast, if I desire to spend the afternoon in the library, I might find myself mulling over whether to go to the movies instead. Here's one way of formulating this idea:

Dispositions-to-Avoid-Reconsidering If $\mathrm{S}$ intends $p$, then $\mathrm{S}$ is disposed to refrain from seriously considering actions that $\mathrm{S}$ believes to be inconsistent with $p$.

Let us grant that this is a feature of intention that the belief-desire theory leaves out. ${ }^{22}$ Still, the noncognitivist need not fret, since this feature is itself formulated entirely in terms that the noncognitivist has a handle on. To see this, consider again Michelle's intention to do no wrong. According to Dispositions-to-Avoid-Reconsidering, this involves a disposition to avoid seriously considering actions that she believes to be wrong. For example, if she believes that kicking kittens is wrong, she'll be disposed to avoid seriously considering kicking kittens. Noncognitivists can make perfect sense of this disposition, since they already have a story about the relevant normative beliefs. More generally, the strategy we used in the case of normative desire will apply equally well to intention: for any putative feature $f$ of its dispositional profile, the trick is to show that we can cash out $f$ using resources that are already available to the noncognitivist.

\section{Fear and Hope}

Turn next to the 'emotive doxastic' attitudes (Anand and Hacquard 2013), such as fear and hope. Suppose Edmund fears that a burglar will break in. What does this involve? For starters, Edmund needs to have at least some degree of belief that a burglar will break in-he cannot fear what he knows for certain will never transpire. But this is not all. If he yearns to be burgled or is indifferent towards home invasion, it would be incorrect to describe his attitude as 'fear.'

This suggests the following belief-desire conditions on fear:

Belief-Desire Account of Fear: If $S$ fears that $p$, then both:

1. S has some degree of belief in $p,{ }^{23}$

2. $\mathrm{S}$ desires $\neg p$.

\footnotetext{
${ }^{22}$ For doubts on this score, see Ridge (1998); Sinhababu (2013, 2017).

${ }^{23}$ Arguably, we should place further constraints on the degree of belief. Perhaps in order to genuinely fear that $p$, S's degree of belief in $p$ needs to be sufficiently high. But it also should not be too high-if Edmund is certain a burglar will break in, it seems wrong to describe him as fearing this outcome. I'll set these complications aside going forward.
} 
Next, compare fear with hope. Like fear, hope seems to require some positive credence that its object will obtain: Sara cannot hope for a promotion if she is certain she won't receive one. But unlike fear, hope requires a desire for its object: if Sara is apathetic about a promotion, or actively shuns one, then she does not hope for one.

This suggests parallel belief-desire conditions on hope:

Belief-Desire Account of Hope If S hopes that $p$, then both:

1. $\mathrm{S}$ has some degree of belief in $p$,

2. $\mathrm{S}$ desires $p .^{24}$

We can use these analyses to get a grip on normative fear and hope. Recall Lyle, who hopes that lying is permissible but fears that it isn't. According to our belief-desire conditions, Lyle's hope involves (i) having some degree of belief that lying is permissible, (ii) desiring that lying is permissible. And his fear involves the same desire, together with the fact that he has some degree of belief that lying is impermissible.

Even if belief and desire are necessary conditions on fear and hope, are they also sufficient conditions? As in the case of intention, this is controversial. But here too we need not commit ourselves to an affirmative answer. Noncognitivists can breathe easy as long as they can make sense of any residual features of fear and hope.

Can they do so? A full assessment would require looking at various candidates for these residual features. But here too I think there is reason to be hopeful. Consider just two further conditions on hope that have been proposed in the recent literature: Meirav (2009) argues that hoping for $p$ requires believing that $p$ is outside of one's control; Milona (forthcoming) argues that hoping for $p$ requires a particular relation between the belief and desire conditions: your degree of belief in $p$ must be part of the cognitive basis for your desire for $p$. Neither of these further conditions poses any special difficulty for the noncognitivist.

A different source of worry comes from the fact that the belief conditions on fear and hope were formulated in terms of degrees of belief rather than binary belief. Even if noncognitivists can account for binary belief, they may face further difficulties explaining degrees thereof. What is it for Lyle to have, say, a .3 credence that lying is wrong?

An argument due to Smith (2002) gives this worry more bite. The simplest way of developing a noncognitivist account of credence is to find some conative attitude that

\footnotetext{
${ }^{24}$ These belief-desire conditions on fear and hope were anticipated by Hume (Treatise 2.3.9). For a more contemporary analysis of fear and hope in terms of these conditions, see Day (1970).
} 
comes in degrees-say, desire or approval. One could then hold that normative credences are degrees of this state. But Smith convincingly argues that any such account will collapse two distinct dimensions of normative judgment: 'certitude' and 'importance.' Certitude is one's degree of confidence in a normative judgment; importance is the degree of wrongness (or rightness) that one judges to obtain. To illustrate, Lyle could have a low degree of confidence (low certitude) that lying is very wrong (high importance). Alternatively, he could have a high degree of confidence (high certitude) that lying is slightly wrong (low importance). Any account that reduces normative credence to strength of desire or approval will lack the structural resources to distinguish between these two states. The worry, then, is that until some superior account is given, noncognitivists will not have earned the right to talk of normative credences, and hence will not be able to use normative credences in their analysis of normative fear and hope.

This is an important concern. However, there at least two reasons for thinking that noncognitivists should not despair. First, throughout this paper we've been granting-at least for the sake of argument-that the noncognitivist has a viable account of normative belief. Plausibly, any adequate account of normative belief will also extend to degrees thereof. So, insofar as we are willing to spot the noncognitivist a story about normative belief, we should also spot them a story about normative credence.

Second, there are at least some potentially promising proposals for dealing with Smith's challenge. The issues here are complex, and a full discussion of the different options is a task for another paper. Here I will just briefly mention one potentially attractive response, developed by Sepielli (2012).

Sepielli starts with the idea-found in both Gibbard (1990) and Schroeder (2008a)that to believe that $\phi$-ing is wrong is not simply to adopt some conative attitude towards $\phi$-ing. Rather, it is to adopt some conative attitudes towards a syndrome of reactive attitudes towards $\phi$-ing. For example, on Gibbard's version of this view, to believe that lying is wrong is to have a pro tanto plan to blame and resent liars. ${ }^{25}$

Sepielli points out that this sort of view has the structure needed to accommodate Smith's distinction. After all, noncognitivists now have two graded attitudes-the conative attitude and the reactive attitude-whereas before they had one. Following Sepielli, we could identify certitude with degrees of the conative attitude, and identify importance with the severity of the reactive attitudes. Thus a .3 credence that lying is very wrong amounts to a low degree of some conative attitude towards severely blaming liars. And

\footnotetext{
${ }^{25}$ For discussion of how this sort of view helps solves the 'negation problem' for expressivism, see Schroeder (2008a: chps.4-5).
} 
a .7 credence that lying is slightly wrong amounts to a high degree of a conative attitude towards mildly blaming liars.

Of course, this particular account of normative credence is far from uncontroversial. $^{26}$ My point is not that this account is necessarily correct, just that there are some potentially promising avenues towards developing a noncognitivist account of normative credence. ${ }^{27}$ Given some such account, the noncognitivist is free to put the notion to work in making sense of fear, hope, and the like.

\section{Factive Attitudes}

Turn next to factive attitudes, such as knowing, realizing, and regretting. Factive attitudes show that a strong version of Belief-Desire Reduction is implausible: we cannot hope to analyze e.g., knowledge entirely in terms of some combination of belief and desire, since no such combination entails truth. Still, it's plausible that certain core features of factive attitudes can be spelled out in terms of belief and desire.

For starters, virtually all factive attitudes entail belief. I cannot know, realize, remember, or regret that my keys are in the car unless I believe my keys are in the car. ${ }^{28}$

\footnotetext{
${ }^{26}$ Bykvist and Olson (2012) raise a number of important challenges for this account, e.g.:

(i) Why is the conative attitude that constitutes normative credence gradable in the same ways as descriptive credence?

(ii) If normative credence and descriptive credence are very different states, why can we make comparative confidence ascriptions (e.g., I'm more certain that $2+2=4$ than that stealing is wrong)?

(iii) According to the Normalization Axiom for normative credence, everyone is rationally required to be certain of the tautology, Either stealing is wrong or it isn't. But on Sepielli's view, this means that everyone is rationally required to have a maximally strong conative attitude towards the tautology: Either I will blame for stealing or I won't $(\mathrm{T})$, which seems implausible.
}

Let me make two brief remarks about how one might address these problems. Arguably, (i) and (ii) are instances of a more general-and by now familiar-question: what explains why normative belief has so much in common with descriptive belief, given that the former is a desire-like state? As we saw in $\S 4.4$, there are two strategies for answering this: the Similarity Strategy and the Identity Strategy. If either strategy works for binary belief, it's natural to hope it will carry over to the fine-grained case. For example, proponents of the Identity Strategy could say that normative and descriptive credence have the same functional role. This would explain why both are gradable, and also why we can make comparative confidence ascriptions.

With regards to (iii), one option is to question whether this implication is really so objectionable. We've seen that one plausible condition on conative attitudes is given by Dispositions-to-Act. According to Dispositions-to-Act, desiring $T$ involves being disposed to act in ways that one believes will satisfy $T$. Now, every action trivially satisfies $T$; moreover, we can know this a priori. So, at least on a purely motivational conception of desire, it seems plausible that rational agents are committed to maximally desiring $T$. For further discussion of these issues, see Beddor (forthcoming).

${ }^{27}$ For an alternative approach, see Ridge (2018).

${ }^{28} \mathrm{An}$ exception is forgetting. But even this attitude can be analyzed in terms of the loss of belief. 
Given this, noncognitivists can use their account of normative belief to get at least a partial purchase on factive attitudes towards normative matters. If Michelle knows (or realizes, or remembers, or regrets) that she did something wrong, this entails that she is in whatever conative state constitutes believing that she did something wrong.

Certain factive attitudes-what are sometimes called the 'emotive factives'-entail desires in addition to beliefs. Take regret. Edmund cannot regret that a burglar broke in unless he wishes that he had not been burgled. More generally:

Belief-Desire Conditions on Regret: If S regrets $p$, then both:

1. S believes $p$,

2. $\mathrm{S}$ desires $\neg p$.

Since noncognitivists already have a handle on normative desires, they can use these conditions to get a partial handle on normative regret. Similar remarks apply, mutatis mutandis, to other emotive factives (e.g., being pleased that one acted justly). ${ }^{29}$

So it seems we can partially analyze factive attitudes in terms of belief and desire. But can the residual features of factive attitudes be explained using noncognitivist resources?

Here too, I think there's reason to be optimistic. The distinguishing feature of factive attitudes is that they entail truth. Luckily, expressivists in the quasi-realist tradition have already shown how they can make sense of normative truth. The standard strategydeveloped in detail by Blackburn (1993, 1998) and embraced by Gibbard (2003)-is to appeal to a minimalist theory of truth. On this view, someone who says, 'It is true that lying is wrong' says the same thing as someone who says, 'Lying is wrong.' In both cases, the speaker expresses their disapproval of lying. Expressivists can use this strategy to make sense of the distinguishing feature of factive attitudes. On this view, when someone says, 'Lyle knows/realizes/regrets that lying is wrong,' they not only ascribe to Lyle a certain conative attitude vis-à-vis lying. They also express that they (the speaker) share this conative attitude. ${ }^{30}$

\footnotetext{
${ }^{29}$ Some hold that emotive factives entail knowledge, not just belief. (See, e.g., Unger (1975); Gordon (1987); Williamson (2000); Dietz (2018).) If, as I'll be arguing momentarily, noncognitivists can make sense of normative knowledge, then they are also in a position to make sense of this stronger entailment.

${ }^{30}$ Other features of factive attitude ascriptions can be analyzed in a similar fashion. For example, both Blackburn $(1996,1998)$ and Gibbard (2003) have argued that noncognitivists can make sense of a 'No Defeaters' condition on knowledge. To illustrate with Blackburn's version of this idea: to say that S's belief is immune to defeat is to say that no improvement in S's epistemic position would result in S abandoning her belief-where the notion of 'improvement' is also understood as the expression of a conative attitude. See also Moss (2013), who argues that expressivists can make room for modal conditions on knowledge, such as safety and sensitivity.
} 
One might worry that if noncognitivists go this route, they'll no longer be in the business of explaining the functional roles of the factive attitudes. Rather, they'll be undertaking a subtly different project: providing an analysis of our ascriptions of factive attitudes. However, I think noncognitivists can take this objection in stride. One of the key moves in the expressivist repertoire is the strategy of 'semantic ascent,' whereby one replaces first-order questions with semantic ones. Invited to give an account of the nature of wrongness, the expressivist demurs, offering instead an analysis of the meaning of 'wrongness' talk. Expressivists should feel free to apply this maneuver to factive attitudes. Invited to give an account of normative knowledge or regret (for example), they can decline, offering instead an analysis of the meaning of sentences of the form, ' $\mathrm{S}$ knows/regrets that $\phi$-ing is wrong.'

Noncognitivists who take this line could-and, I think, should-deny that it's possible to give a full functional analysis of factive attitudes (at least in any traditional sense). Still, their semantic analysis of factive attitude ascriptions comes with substantive psychological implications. In particular, it entails various belief-desire conditions (of the sort discussed above). Indeed, these conditions could plausibly be viewed as constituting a functional core to the factive attitudes-a core that exhausts the causal role of these attitudes in explaining behavior. Since this core is explained in noncognitivist-friendly terms, and since the residual features of the factive attitude ascriptions (e.g., their factivity) can also be captured using expressivist resources, the resulting analysis has good claim to satisfying the Explanatory Requirement.

\section{Wondering and Supposing}

In making the case for Belief-Desire Reduction, I've looked at intention, emotive doxastics, and factive attitudes. But there are other attitudes that one can take towards normative matters-attitudes that might appear to be less amenable to Belief-Desire Re-

duction. For example, one can wonder whether lying is wrong; one can also suppose or hypothesize that it is. How should noncognitivists understand these attitudes?

While my remarks here will be somewhat speculative, I think a preliminary case can be made for thinking that even these attitudes can be understood in terms of belief and desire.

Start with wondering. We might hazard an analysis of wondering as desiring to know. On this view, for Lyle to wonder whether lying is wrong is for him to desire to know whether lying is wrong. According to the analysis of desire advanced here, this entails 
that Lyle is disposed to act in ways that he thinks will lead him to attain this knowledge (talking to ethicists, ruminating on the consequences of lying, etc.). It also entails that Lyle is disposed to experience pleasure upon believing that he has come to know whether lying is wrong, and to experience displeasure upon believing that this knowledge has eluded to him. Finally, noncognitivists can appeal to their preferred treatment of normative knowledge (more precisely: normative knowledge ascriptions) to tell us the conditions under which Lyle's desire would be fulfilled-that is, the conditions under which he would count as knowing that lying is wrong. ${ }^{31}$

What about supposing? Here I suggest borrowing an idea from Köhler (2017: 206207). Köhler proposes that noncognitivists can understand supposition (or 'entertaining the thought that...') as a sort of 'make-believe belief.' To suppose $p$, on this view, is to simulate the state of believing $p$ in certain respects-for example, by asserting $p$, or by pursuing the logical consequences of $p^{32}$ Of course, this analysis would need to be fleshed out in much more detail. But, even in its bare-bones form, it should be clear that this analysis is available to the noncognitivist. In the noncognitivist's hands, it would mean that when Lyle supposes that lying is wrong he is simulating having whatever noncognitive attitude constitutes the belief that lying is wrong.

\section{Coda: A Comparison with Hybrid Views}

In this paper, I've outlined a solution to the Many Attitudes Problem. In developing my solution, I assumed a 'pure' version of noncognitivism, according to which normative beliefs are just desire-like states. However, recently a number of authors have discarded pure noncognitivism in favor of hybrid views. ${ }^{33}$ According to hybrid theorists, normative belief requires both a descriptive belief and a desire-like state. One reason why hybrid views have generated such excitement is that they promise to avoid many of the problems afflicting pure noncognitivism-for example, the Frege-Geach Problem. ${ }^{34}$ Do they

\footnotetext{
${ }^{31}$ Friedman also stresses the connection between wondering and knowledge, describing wondering as an attitude that is "relieved by coming to know" (2013: 145). However, she resists any attempt to analyze wonder as a desire to know, on the grounds that desiring is a state whereas wondering is an activity. It is not entirely clear to me that the verb 'wonder' never denotes a state, but let us set that aside. Even if Friedman is correct, we might appeal to the distinction between occurrent and standing desires, identifying wondering with an occurrent desire to know.

${ }^{32}$ See Goldman (2006: chp.2) for a proposal along these lines.

${ }^{33}$ See, among others, Ridge (2006b, 2007, 2014); Boisvert (2008); Hay (2013); Fletcher and Ridge (2014); Laskowski (2019); Perl (2018). For related ideas, see Toppinen (2013); Schroeder (2013a).

${ }^{34}$ See e.g., Ridge (2006b). For reservations, see Schroeder (2009).
} 
also avoid the Many Attitudes Problem? By way of conclusion, I'll consider this question and give some reason for thinking the answer is no. If I'm right, then hybrid views turn out to be at an important disadvantage when compared to pure noncognitivist views.

To evaluate whether hybrid views avoid the Many Attitudes Problem, it will help to have a concrete hybrid view on the table. Here, then, is a simple proposal. For Lyle to believe that lying is wrong is for him to both (i) believe that lying instantiates some natural property $N$ (e.g., failing to promote happiness), (ii) disapprove of actions that instantiate $N$.

This gives us a hybrid theory of normative belief. How can it be extended to nondoxastic attitudes?

Here's a natural thought. For any attitude $\alpha$, an agent $\alpha$ s that $\phi$-ing is wrong if and only if they both (i) stand in $\alpha$ towards the descriptive propostion that $\phi$-ing is $N$, (ii) disapprove of actions that instantiate $N$. Thus for Lyle to wonder whether lying is wrong is for him to be in two states: a state of wondering whether lying instantiates $N$, and state of disapproval of actions that instantiate $N$. For him to fear that lying is wrong is for him to be in both a state of fearing that lying instantiates $N$, and a state of disapproval of $N$-instantiating actions. Etc.

As Ridge (2014: 161) and Toppinen (2017) note, the hybrid approach seems to deliver a straightforward solution to the Many Attitudes Problem. After all, one key feature of this approach is that desiring, hoping, wondering and the like are always directed towards descriptive contents. What makes one of these attitudes normative is not some distinctly normative content, but rather the accompaniment of a further desire-like attitude. Hybrid theories thus appear to sidestep the main challenge that I've tackled in this paper: fleshing out a functional role for various nondoxastic attitudes that applies to both descriptive and normative contents.

Alas, I think this easy solution is too easy. On closer examination, the hybrid approach flounders on an important class of cases: cases of full descriptive information. To illustrate, suppose that Eugenia is an experienced doctor who works with the terminally ill. A suffering patient has requested Eugenia's assistance in taking his life. Eugenia might wonder whether it would be wrong to comply with the patient's request. According to the hybrid analysis, Eugenia is wondering whether the action, complying with the patient's request instantiates $N$ (where $N$ is some property she happens to disapprove of). But this seems incorrect. We can stipulate that Eugenia knows exactly which natural properties this action would instantiate. (She knows exactly how much suffering 
euthanasia would relieve, exactly how it would affect the patient's family members, etc.) In such a case, it seems closer to the mark to say that Eugenia is wondering whether she should disapprove of her action in virtue of these properties.

The problem is not confined to the simple hybrid theory I've used for illustration. Consider, for example, the advisor-based hybrid view in Ridge (2006b, 2007). On this view, believing euthanasia is wrong involves both (i) believing that some particular advisor would disapprove of euthanasia, (ii) approving of the advisor mentioned in (i). Generalized to any attitude $\alpha$, the idea would be that $\alpha$-ing that $\phi$-ing is wrong involves both (i) standing in $\alpha$ towards the descriptive proposition that some particular advisor would disapprove of $\phi$-ing, (ii) approving of the advisor in question. This account also delivers the wrong results when it comes to Eugenia. After all, Eugenia might have no doubts whatsoever about the sort of advisor who would disapprove of euthanasia. (She could be certain that a Kantian advisor would disapprove of euthanasia, and that a utilitarian advisor would not.) Still, she might wonder whether euthanasia is wrong, precisely because she is uncertain which advisor to hold in high regard. ${ }^{35}$

The problem is also not specific to wondering-it arises with other attitudes. Suppose that Eugenia complies with the patient's request. Ruminating on her decision, she might fear that she acted wrongly. The hybrid view analyzes her mental state as follows: she fears that her action instantiated $N$ (where $N$ is again some property she holds in disapproval). Again, this seems to misdescribe the case. It seems closer to the mark to say that she fears that she should disapprove of her action in virtue of some of the properties it instantiated.

Indeed, as a referee helpfully observes, the problem even arises for the hybrid theorist's attitude of choice: belief. After all, the root of the problem is this. The most straightforward version of the hybrid strategy presupposes that there is always some

\footnotetext{
${ }^{35}$ In more recent work, Ridge (2014) has substantively revised his view. On his revised view, believing that euthanasia is wrong involves two components: a normative perspective (understood as a conative state) and a descriptive belief that any admissible standard would give low marks to euthanasia, where the 'admissible standards' are those that are not ruled out by the normative perspective. Generalized to e.g., wondering, the idea would be that wondering whether $\phi$-ing is wrong involves both (i) a normative perspective $n$, (ii) wondering whether $\phi$-ing would be given low marks by any $n$-admissible standard. On the face of it, this account is better-equipped to handle our problem. After all, Eugenia could know all of the descriptive facts about euthanasia while still wondering whether euthanasia is wrong, since she could wonder whether any standard consistent with her normative perspective permits euthanasia. But a residual worry remains. Note that on this diagnosis, Eugenia is really wondering about the consequences of her (current) normative perspective. This seems to misdescribe the case. Intuitively, Eugenia is not trying to figure out which courses of action she currently disapproves of. Rather, it seems she is trying to make up her mind which courses of action she should disapprove of.
} 
natural property (or some particular sort of advisor) that the agent holds in disapproval (or approval). Given this assumption, it follows that if someone learns all of the descriptive facts about an action, that should settle the question of whether they believe that action is permissible. But as cases like Eugenia reveal, this assumption does not always hold. Even though Eugenia knows all the descriptive facts, she still has not settled on a belief about the moral status of euthanasia. ${ }^{36}$

Taking stock: at first blush, hybrid theories seemed to have an easy way out of the Many Attitudes Problem. But on closer inspection, the most straightforward versions of the hybrid view struggle to account for cases of full descriptive information. It's possible that more sophisticated hybrid views can overcome this problem-I will leave this as an open question. ${ }^{37}$ However, it is a point in favor of the pure noncognitivist solution to the Many Attitudes Problem that it does not face this challenge. After all, the pure noncognitivist need not assume that there is always some descriptive property/advisor that the agent holds in approval/disapproval. ${ }^{38}$

\section{References}

Pranav Anand and Valentine Hacquard. Epistemics and Attitudes. Semantics and Pragmatics, 6: 1-59, 2013.

G.E.M. Anscombe. Intention. Harvard University Press, Cambridge, MA, 1957.

Robert Audi. Intending. Journal of Philosophy, 70(13):387-403, 1973.

\footnotetext{
${ }^{36}$ See Bykvist and Olson (2009) for related worries about whether hybrid views can handle the full range of cases of normative uncertainty.

${ }^{37}$ In addition to Ridge's recent view (discussed in fn. 35), one promising place to look is the hybrid theory of normative concepts in Laskowski (2019). On Laskowski's view, a normative concept always picks out some natural property-say, failing to maximize pleasure. Still, the normative concept is distinct from the concept of failing to maximize pleasure. On this view, for Eugenia to believe euthanasia is wrong is for her to both (i) believe euthanasia is $c_{\mathrm{WRONG}}$, (ii) desire to avoid actions that are $c_{\mathrm{WRONG}}$, where $c_{\mathrm{WRONG}}$ is a normative concept that picks out some natural property. This helps with our problem: Eugenia could know exactly which natural properties an action exhibits, while still wondering whether that action is wrong, since she might not know which natural property $c_{\text {Wrong }}$ denotes (for familiar Frege's Puzzle reasons). However, difficult questions remain. In particular, can we say anything systematic about the intensions of normative concepts? Perhaps the most straightforward answer would be that the intension of $c_{\mathrm{WRONG}}$ is a function from an agent $x$ and a time $t$ to whatever natural property $x$ holds in disapproval at $t$. But note that this answer assumes that there is always some natural property that the agent holds in disapproval (even if they do not know what that property is). But this seems to misdescribe Eugenia's case, for precisely the sort of reasons discussed in fn. 35: Eugenia is not uncertain of what property she currently disapproves of, but rather what property to disapprove of. So while I think the hybrid concept approach is promising, more work is needed before it can claim to offer a fully satisfactory solution to our problem.

${ }^{38}$ Thanks to Simon Goldstein, Nick Laskowski, the NUS philosophy reading group, and two anonymous referees for helpful comments.
} 
A.J. Ayer. Language, Truth, and Logic. Dover, New York, 1936.

Bob Beddor. Noncognitivism and Epistemic Evaluations. Philosophers' Imprint, 19(10):1-27, 2019.

Bob Beddor. Fallibility for Expressivists. Australasian fournal of Philosophy, forthcoming.

Bob Beddor and Carlotta Pavese. Modal Virtue Epistemology. Philosophy and Phenomenological

Research, Advance Publication Online, 2018. doi: 10.1111/phpr.12562.

Gunnar Björnsson and Tristram McPherson. Moral Attitudes for Non-Cognitivists: Solving the Specification Problem. Mind, 123(489):1-38, 2014.

Simon Blackburn. Essays in Quasi-Realism. Oxford University Press, Oxford, 1993.

Simon Blackburn. Securing the Nots: Moral Epistemology for the Quasi-Realist. In Timmons, editor, Moral Knowledge? New Readings in Moral Epistemology. Oxford University Press, New York, 1996.

Simon Blackburn. Ruling Passions. Clarendon Press, Oxford, 1998.

Daniel Boisvert. Expressive-Assertivism. Pacific Philosophical Quarterly, 89:169-203, 2008.

Michael Bratman. Intention, Plans, and Practical Reason. Harvard University Press, Cambridge, MA, 1987.

Krister Bykvist and Jonas Olson. Expressivism and Moral Certitude. Philosophical Quarterly, 59: 202-215, 2009.

Krister Bykvist and Jonas Olson. Against the Being For Account of Normative Certitude. Fournal of Ethics and Social Philosophy, 6(2):1-8, 2012.

Donald Davidson. Actions, Reasons, and Causes. fournal of Philosophy, 60(23):685-700, 1963.

Wayne Davis. A Causal Theory of Intending. American Philosophical Quarterly, 21(1):43-54, 1984.

J.P. Day. The Anatomy of Fear and Hope. Mind, 79(315):369-384, 1970.

Christina Dietz. Reasons and Factive Emotions. Philosophical Studies, 175:1681-1691, 2018.

John Eriksson and Ragnar Francén Olinder. Non-Cognitivism and the Classification Account of Moral Uncertainty. Australasian fournal of Philosophy, 94(4):719-735, 2016.

Guy Fletcher and Michael Ridge. Having it Both Ways: Hybrid Theories and Modern Metaethics. Oxford University Press, New York, 2014.

Jane Friedman. Question-Directed Attitudes. Philosophical Perspectives, 27(1):145-174, 2013.

Allan Gibbard. Wise Choices, Apt Feelings. Harvard University Press, Cambridge, MA, 1990.

Allan Gibbard. Thinking How to Live. Harvard University Press, Cambridge, MA, 2003.

Allan Gibbard. Meaning and Normativity. Oxford University Press, Oxford, 2013.

Alvin Goldman. Simulating Minds: The Philosophy, Psychology, and Neuroscience of Mindreading. Oxford University Press, New York, 2006.

R.M. Gordon. The Structure of Emotion: Investigations in Cognitive Philosophy. Cambridge University Press, Cambridge, 1987.

Paul Grice. Intentions and Uncertainty. Proceedings of the British Academy, 57:263-279, 1971.

Gilbert Harman. Practical Reasoning. Review of Metaphysics, 29(3):431-463, 1976. 
Ryan Hay. Hybrid Expressivism and the Analogy Between Pejoratives and Moral Language. European fournal of Philosophy, 21(3):450-474, 2013.

Terry Horgan and Mark Timmons. Cognitivist Expressivism. In Horgan and Timmons, editors, Metaethics Afrer Moore. Oxford University Press, New York, 2006.

Mark Johnston. How to Speak of the Colors. Philosophical Studies, 68:221-263, 1992.

Sebastian Köhler. Do Expressivists Have an Attitude Problem? Ethics, 123(3):479-507, 2013.

Sebastian Köhler. Expressivism, Belief, and All that. fournal of Philosophy, 114(4):189-207, 2017.

Nicholas Laskowski. The Sense of Incredibility in Ethics. Philosophical Studies, 176(1):93-115, 2019.

David Lewis. Radical Interpretation. Synthese, 23:331-344, 1974.

David Manley and Ryan Wasserman. On Linking Dispositions and Conditionals. Mind, 117(465): 59-84, 2008.

Berislav Marušić and John Schwenkler. Intending is Believing: A Defense of Strong Cognitivism. Analytic Philosophy, 59(3):309-340, 2018.

Ariel Meirav. The Nature of Hope. Ratio, 22(2):216-233, 2009.

Michael Milona. Finding Hope. Canadian fournal of Philosophy, forthcoming.

Carolyn Morillo. The Reward Event and Motivation. Journal of Philosophy, 87:169-186, 1990.

Sarah Moss. Epistemology Formalized. Philosophical Review, 122(1):1-43, 2013.

Caleb Perl. A User's Guide to Hybrid Tools. Mind, Advance Publication Online, 2018. doi: 10.1093/mind/fzy063.

Michael Ridge. Humean Intentions. American Philosophical Quarterly, 35:157-178, 1998.

Michael Ridge. Saving the Ethical Appearances. Mind, 115(459):633-650, 2006a.

Michael Ridge. Ecumenical Expressivism: Finessing Frege. Ethics, 116:302-336, $2006 \mathrm{~b}$.

Michael Ridge. Ecumenical Expressivism: The Best of Both Worlds? In Shafer-Landau, editor, Oxford Studies in Metaethics, volume 2. Oxford University Press, 2007.

Michael Ridge. Impassioned Belief. Oxford University Press, New York, 2014.

Michael Ridge. Normative Certitude for Expressivists. Synthese, Advance Publication Online, 2018. doi: 10.1007/s11229-018-1884-7.

Mark Schroeder. Being For: Evaluating the Semantic Program of Expressivism. Oxford University Press, Oxford, 2008a.

Mark Schroeder. What is the Frege-Geach Problem? Philosophy Compass, 3(4):703-720, 2008b.

Mark Schroeder. Hybrid Expressivism: Virtues and Vices. Ethics, 119:257-309, 2009.

Mark Schroeder. Noncognitivism in Ethics. Routledge, New York, 2010.

Mark Schroeder. Tempered Expressivism. In Shafer-Landau, editor, Oxford Studies in Metaethics, volume 8. Oxford University Press, New York, 2013a.

Mark Schroeder. Two Roles for Propositions. Noûs, 47(3):409-430, 2013b.

George F. Schueler. Desire: its Role in Practical Reason and the Explanation of Action. MIT Press, Cambridge, MA, 1995.

John Searle. Intentionality. Cambridge University Press, Cambridge, 1983. 
Andrew Sepielli. Normative Uncertainty for Non-Cognitivists. Philosophical Studies, 160:191207, 2012.

Derek Shiller. The Problem of Other Attitudes. American Philosophical Quarterly, 54(2):141-152, 2017.

Neil Sinhababu. The Desire-Belief Account of Intention Explains Everything. Noûs, 47(4):680696, 2013.

Neil Sinhababu. Humean Nature. Oxford University Press, New York, 2017.

Michael Smith. The Humean Theory of Motivation. Mind, 96:36-61, 1987.

Michael Smith. Evaluation, Uncertainty, and Motivation. Ethical Theory and Moral Practice, 5(3): 305-320, 2002.

Robert Stalnaker. Inquiry. MIT Press, Cambridge, MA, 1984.

Charles L. Stevenson. The Emotive Meaning of Ethical Terms. Mind, 46:14-31, 1937.

Galen Strawson. Mental Reality. MIT Press, Cambridge, MA, 1994.

Sigrun Svavarsdóttir. Moral Cognitivism and Motivation. The Philosophical Review, 108:161-219, 1999.

Teemu Toppinen. Believing in Expressivism. In Shafer-Landau, editor, Oxford Studies in Metaethics, volume 8. Oxford University Press, New York, 2013.

Teemu Toppinen. Hybrid Accounts of Ethical Thought and Talk. In Routledge Handbook of Metaethics, pages 243-259. Routledge, 2017.

Peter Unger. Ignorance. Clarendon Press, Oxford, 1975.

Barbara Vetter. Dispositions without Conditionals. Mind, 123(489):129-156, 2014.

Jay Wallace. Normativity, Commitment, and Instrumental Reason. Philosophers' Imprint, 1(3): 1-26, 2001.

Timothy Williamson. Knowledge and its Limits. Oxford University Press, Oxford, 2000.

Seth Yalcin. Bayesian Expressivism. Proceedings of the Aristotelian Society, 112(2):123-160, 2012. 